\title{
An exceptional rainfall event in the central western Pyrenees: spatial patterns in discharge and impact
}

M.P. Serrano-Muela (1), E. Nadal-Romero (2), Noemí Lana-Renault (3), J.C. GonzálezHidalgo (3), J.I. López-Moreno (1), S. Beguería (4), Y. Sanjuan (1), J.M. García-Ruiz

(1) Instituto Pirenaico de Ecología, CSIC, Campus de Aula Dei, Apartado 13.034, 50080-Zaragoza, Spain.

(2) Department of Geography and Land Management, University of Zaragoza, 50009Zaragoza, Spain.

32) Area of Physical Geography, Department of Human Sciences, Luis Vives Building, University of La Rioja, 26004-Logroño, Spain.

(3) Department of Geography and Land Management, University of Zaragoza, 50009Zaragoza, Spain.

(4) Estación Experimental de Aula Dei, CSIC, Campus de Aula Dei, Apartado 13.034, 50080-Zaragoza, Spain.

*Corresponding author.E-mail: humberto@ipe.csic.es

\begin{abstract}
An exceptional rainfall and hydrological event occurred on 19-21 October 2012 in the central western Pyrenees, and was particularly significant in the Upper Aragón River basin and its tributaries, mainly the Irati River. Analysis of historical records showed that, considered separately, the event of 19 and 20 October ranked between the 2nd and 5th highest most extreme daily precipitation events. For the two days combined (with a total between 200 and $260 \mathrm{~mm}$ ), the precipitation event was the most extreme two-day event among all observation stations but one. The consequent flood destroyed part of an urban area and a long stretch of a national road, triggered landslides, enlarged the alluvial plain and caused generalized soil erosion in cultivated fields cropped with winter cereals. Badlands in the marls of the Inner Depression yielded high volumes of sediment. The floods in the tributaries were relatively moderate (return periods of 14-42 years), whereas in the Upper Aragón River the flood corresponded to a return period of approximately 400-500 years, and to 142 years at the end of the Yesa reservoir,
\end{abstract}


although difficulties in estimating the discharge increased the uncertainty of these values. The Yesa and Itoiz reservoirs considerably reduced the intensity of the flood in the middle and lower Aragón River, and confirmed the importance of the water level in the reservoirs when such rainfall events occur. The water storage in the Yesa reservoir increased from 16 to $53 \%$ as a consequence of the event. More integrated studies are necessary to decrease the risks associated with flood hazards. This is particularly the case in mountain areas, where the steep slopes and longitudinal gradients of the rivers shorten the concentration time of floods, and increase the energy that erodes channels and riverbanks.

KEY WORDS exceptional rainfall event, flood, flood propagation, Yesa reservoir, central Pyrenees.

\section{INTRODUCTION}

Exceptional rainstorm events are defined as those occurring with a recurrence interval of approximately 100 years, and which cause minor landscape changes (Wolman and Gerson, 1978; Jacobson et al., 1989; Benito et al., 1998; Grodek et al., 2012), whereas extreme events are those related to large hillslope and alluvial plain geomorphological changes with recurrence intervals of more than 500 years (Wolman and Gerson, 1978). Both types of event trigger large floods, and in some cases the destruction of bridges and dams, lateral erosion and the loss of human life (Poesen and Hooke, 1997; Wainwright and Thornes, 2004). In general, during such rainfall events the entire basin is activated, contributing to increased discharge and sediment load. In most cases, shallow landslides also occur on the hillslopes and riverbanks. The transport of huge quantities of sediment to the fluvial channel causes changes in the main streambed and tributaries, changes in channel morphology and the formation of new bars, and erosion in some stretches of waterways and sediment accumulation in others (Romero Díaz et al., 1992; Calvet and Lemartinel, 2002).

Extremely intense rainstorms are common in the Mediterranean region, particularly in autumn, with precipitation events of more than $200 \mathrm{~mm}$ occurring over a few hours (López-Bermúdez and Romero-Díaz, 1993; Poesen and Hooke, 1997; González Hidalgo et al., 2003; Bracken et al., 2008). According to the Spanish National Meteorological Agency (AEMet), the maximum precipitation event over a 24-hour period in Spain is $600 \mathrm{~mm}$, recorded on 19 October 1973 at Albuñol and Zúrgena, 
which are located in southeast Spain; the next highest record is $426 \mathrm{~mm}$ at Cofrentes and Jalance on the Valencian coast. With respect to two consecutive days, the recorded maximum precipitation event is usually cited as $817 \mathrm{~mm}$, which occurred at Olive (Valencia) on 2-3 November 1987, although the figure is controversial. These extreme events usually occur because of warming of the Mediterranean Sea at the end of summer, and the consequent presence of unstable and humid air masses (the Mediterranean low) that can evolve into cut-off systems. These can result in very active thermodynamically unstable depressions (Nieto et al., 2005) that commonly trigger trigger high intensity rainstorms over periods of two or three days.

The presence of steep and complex relief close to the Mediterranean coast explains the short concentration time of overland flow and the rapidity of propagation of floods, both of which increase destructive capacity (Thornes, 1976; Poesen and Hooke, 1997; Wainwright and Thornes, 2004). Gaume et al. (2009) noted that the most extreme flash floods occur in the Mediterranean region, where the discharge can change from zero to several hundred cubic meters in a few minutes (Camarasa Belmonte and Segura Beltrán, 2001).

Exceptional and extreme events are also possible at distance from the coast, in both mountainous and flat areas. Thus, during an extreme rainfall event in November 1982, various weather stations in the central Pyrenees recorded more than $200 \mathrm{~mm}$ over three days; this was associated with destructive floods in the main Pyrenean rivers and alluvial fans, as described by Martí-Bono and Puigdefábregas (1983). On 7 August 1996 a catastrophic flood occurred in the Arás ravine alluvial fan (central Spanish Pyrenees) as a consequence of approximately $220 \mathrm{~mm}$ of rainfall that occurred in $1.25 \mathrm{~h}$ (White et al., 1997) and caused a flood of approximately $300 \mathrm{~m}^{3} \mathrm{~s}^{-1}$ in a basin of only $18 \mathrm{~km}^{2}$. The flood destroyed a camping site located in the alluvial fan, killing 89 people. Ortega and Garzón Heydt (2009) record that in a flat area of the central-western Iberian Peninsula (Guadiana River basin), a flash flood in the Rivillas ravine in November 1997 had a peak discharge of $799 \mathrm{~m}^{3} \mathrm{~s}^{-1}$ and caused the loss of 23 lives together with the loss of most of the fertile soil horizon on the alluvial plain.

On 19-21 October 2012 an exceptional rainfall and flood event occurred in the central western Pyrenees. This event mainly affected the Upper Aragón River basin and to a lesser extent the Gállego River, and had a major impact in a small area in the Pyrenean foothills (the Riguel and Arba rivers basins) (Acín et al., 2012). No human lives were lost, although the floods destroyed houses and roads, enlarged some parts of 
the alluvial plain, and caused landslides in deforested areas. The objectives of this study were to: (i) assess this event in a broader temporal scale; (ii) analyze the spatial organization of rainfall and floods in the main river and tributaries involved; (iii) study the role of the Yesa reservoir during the event; the reservoir is located at the lower end of the upper course of the Aragón River; (iv) analyze the management and propagation of the flood in relation to other rivers in the central Pyrenees in terms of the control of large floods in the middle and lower Ebro River; and (v) assess the behaviour and consequences of the flood in terms of improving understanding and management of mountain basins.

\section{STUDY AREA}

The study was mainly focused on the Upper Aragón River basin $\left(2182 \mathrm{~km}^{2}\right.$ in area; Fig. 1). The altitude ranges from $<500 \mathrm{~m}$ a.s.l. at the Yesa reservoir to more than $2500 \mathrm{~m}$ a.s.l. in the north of the basin (Collarada Peak, 2886 m). The Aragón River is orientated in a north-south direction, and traverses a Paleozoic area (limestone, shale and clay), the Inner Ranges (limestone and sandstone), and the Flysch Sector (sandstone and marl alternating in thin beds). It reaches the Inner Depression (marl) and flows westward to the Yesa reservoir, downstream of which it flows southward across various lithological outcrops in the Ebro Depression (sandstone, clay and gypsum) until it enters the Ebro River. In 1986 the original capacity of the Yesa reservoir $\left(470 \mathrm{hm}^{3}\right)$ was recalculated by bathymetry to be $450 \mathrm{hm}^{3}$, indicating an annual mean siltation rate of $0.79 \mathrm{hm}^{3}$. The spillways of the Yesa reservoir have a maximum floodwater overflow capacity of $2240 \mathrm{~m}^{3} \mathrm{~s}^{-1}$.

In its course across the Inner Depression, the Aragón River receives input from several major tributaries originating in the Inner Sierras, including the Estarrún, Aragón Subordán, Veral and Esca rivers, the latter of which flows directly into the Yesa reservoir. Downstream of the reservoir the Aragón River has another major tributary, the Irati River, which is regulated in its headwaters by a large, recently constructed reservoir (the Itoiz reservoir: capacity, $417 \mathrm{hm}^{3}$ ).

The average annual precipitation in the northernmost sector of the Aragón River basin exceeds $1500 \mathrm{~mm}$, with $800 \mathrm{~mm}$ occurring in the Inner Depression. The wet season is from October to June, with the greatest volumes of precipitation occurring in autumn and spring. During the cold season rainfall accumulates as snow above $1600 \mathrm{~m}$ a.s.l., and this has a significant effect on the monthly distribution of discharges. Intense 
rainstorms are particularly frequent in autumn, mainly in October and November (García-Ruiz et al., 2000), although they can occur at any time of the year (White et al., 1997).

Human activity has had a major impact on plant cover in the region. The upper forest belt (1600-2100 m) was burnt during the Middle and Modern Ages, and transformed into subalpine grasslands. The cultivated areas were traditionally located below $1600 \mathrm{~m}$ in the valley bottoms and on perched flats and steep south-facing slopes. Forests remained relatively well preserved on north-facing slopes, and on slopes having any aspect between 1600 and $1800 \mathrm{~m}$. During the 20th century most of the cultivated fields were abandoned, particularly during the 1950s and 1960s, except those on the valley bottoms and in the Inner Depression. This explains the recent expansion of forests and shrubs (Lasanta et al., 2005).

Figure 2 shows the regime of the Aragón River at Jaca (López-Moreno, 2006). The maximum average monthly discharge occurs in May (followed by June), highlighting the influence of snowmelt, whereas the discharge in winter is relatively low because of snow accumulation in the headwaters. Low discharge levels occur in summer, and are slightly high in autumn. The average annual discharge at Jaca is $6.4 \mathrm{~m}^{3}$ $\mathrm{s}^{-1}$, and at the head of the Yesa reservoir is $30.9 \mathrm{~m}^{3} \mathrm{~s}^{-1}$. The Aragón and Esca rivers together discharge a total of $44 \mathrm{~m}^{3} \mathrm{~s}^{-1}$ into the Yesa reservoir. A statistically significant negative trend in the Pyrenean river discharges has been observed in recent decades (Beguería et al., 2003), and this has affected management of the Yesa reservoir (LópezMoreno et al., 2004).

\section{METHODS}

Discharge data obtained from the Ebro River Basin Authority for 19-21 October 2012 were used in the study. These data are openly available from the Authoriry's website, and include: (i) the peak discharge; and (ii) the hydrograph corresponding to any event. We downloaded the hydrographs for various gauging stations in the Upper Aragón River basin (Fig. 1) and its tributaries. We also obtained information on the water stored in the Yesa reservoir $\left(450 \mathrm{hm}^{3}\right)$ and the water delivered downstream of the dam.

To assess the management of the entire Aragón River basin during the rainstorm event we also downloaded the hydrographs of the flood recorded at various gauging stations in the main tributary (the Irati River), which is regulated by a large reservoir at 
Itoiz. Its confluence with the Aragón River occurs $8 \mathrm{~km}$ downstream of the Yesa reservoir. Information from the Caparroso gauging station was also obtained. This station is located $25 \mathrm{~km}$ upstream of the confluence of the Aragón River with the Ebro River. The discharges measured at the Miranda de Ebro, Castejón de Ebro and Zaragoza gauging stations were analyzed to assess the effects of the Aragón River flood and other minor tributaries on the Ebro River.

For comparative purposes, information on discharges at various gauging stations in the Gállego River (immediately east of the Aragón basin) and of the Arba basin (located to the south and east of the Aragón basin) was also downloaded. The Arba River (and particularly one of its tributaries, the Riguel River) was affected by an extraordinary flood, although uncertainties in the measurement of the discharge (because of floodwaters overtopping the bank) made this information less hydrologically interesting.

A series of calculations was made based on the peak discharge, including the return period and the specific discharge $\left(\mathrm{l} \mathrm{s}^{-1} \mathrm{~km}^{-2}\right)$. Rainfall records for 19-21 October at various weather stations were obtained from the Ebro River Basin Authority. Meteorological synoptic charts from the AEMet (500 hPa and $1000 \mathrm{mb}$ ) were used to study the dynamic characteristics of the rainstorm. Values of precipitation and peak discharges for 19 and 20 October at several gauging stations were compared with historical records to estimate the corresponding return periods. Peak discharges, and one-day and two-days peaks over threshold series were obtained for each weather and gauging station, using a threshold corresponding to the 90th percentile, and the resulting data were fitted to a Generalized Pareto distribution using the unbiased probability weighted moments method (Coles, 2001). Previous studies demonstrated that this distribution provides the best fit to heavy precipitation and high runoff series in the Pyrenees (Beguería, 2005; López-Moreno et al., 2006).

Fieldwork enabled detection of the occurrence of landslides on the hillslopes, lateral erosion of the riverbanks, channel changes, and damage to houses and infrastructure.

\section{RESULTS}

\section{Rainfall characteristics}

During the days 19-21 October 2012 an intense, complex and long-lasting rainstorm occurred in both the French and Spanish central western Pyrenees and in the 
central Ebro Depression. During its final stages the rainstorm also affected the Mediterranean coast of northeast Spain. The most intense rainfall was concentrated in the headwaters of the Aragón and Gállego rivers, and in a small sector of the central Ebro Depression associated with the Pre-Pyrenees, in the region of Cinco Villas (Riguel River basin), where large floods occurred (Fig. 3).

The atmospheric conditions are shown in the daily sequence from 19 to 21 October (from $0000 \mathrm{~h}$ ). The evolution of the synoptic conditions shows a trough at $500 \mathrm{hPa}$ extending from the western part of the British Isles to northern Morocco, combined with a low surface pressure located to the west of the British Isles. The migration of the trough axis to the east and its evolution during 20 and 21 October, associated with cold fronts (Fig. 4) and various moist air advections, produced spatial and temporal differences.

Table 1 shows the main features of the precipitation, organized to highlights its spatial and temporal distribution. In general, the highest total precipitation for the three days occurred in the headwaters of the Aragón River and its tributaries: $253 \mathrm{~mm}$ at Belagua (Esca River), $253 \mathrm{~mm}$ at Javierregay (Aragón Subordán River), $235 \mathrm{~mm}$ at Canfranc and 240 mm at Candanchú (Aragón River), and 222 mm at Panticosa and 209 mm at Lanuza (Gállego River). The rainstorms were also intense in the middle Gállego River Basin (228 mm at Asabón, $211 \mathrm{~mm}$ at Loarre), and in the Riguel River basin, but clearly decreased towards the middle of the Ebro Depression (Sotonera, $106 \mathrm{~mm}$; Zaragoza, $66 \mathrm{~mm}$ ). Based on Table 1, three distinct rainfall periods can be identified:

(i) An initial period of high rainfall intensity between 0515 and $1430 \mathrm{~h}$ on October 19, which mainly affected the northwestern sector of the study area, with some particularly intense rainstorms occurring at Anduñana (Irati River), Yesa (Aragón River), Isaba (Esca River), Biniés (Veral River) and Javierregay (Aragón Subordán River); the intensity decreased towards the east and southeast, where the precipitation was moderate.

(ii) A second period of high rainfall intensity that occurred between $1430 \mathrm{hr}$ on 19 October and $0200 \mathrm{~h}$ on 20 October, and almost exclusively affected the headwaters of the Aragón River: $139 \mathrm{~mm}$ at Canfranc, $112 \mathrm{~mm}$ at Albarún, and $112 \mathrm{~mm}$ at Candanchú. Low levels of rainfall were recorded in the headwaters of the Gállego River (approximately $55 \mathrm{~mm}$ ), and even lower levels occurred in the rest of the Aragón basin (particularly in the Irati River basin), suggesting a displacement of the most intense rainfall nucleus towards the east. The location of the most intense rainfall in the 
headwaters of the Aragón River basin during this second period suggests the occurrence of local reactivation by orographic uplift combined with the beginning of a cut-off system, which was responsible for the third period of rainfall intensity. Unfortunately, no weather stations are located at the foot or on the hillslopes of the Collarada Massif to enable confirmation of this orographic effect, although the hydrograph of the flood event at Jaca and Martes (see below) suggests that a very intense onset of precipitation occurred in some sectors of the Aragón River basin.

(iii) A third period of high rainfall intensity from 0200 to 2345 h on October 20 coincided with the arrival of humid and relatively warm winds from the southeast, related to the cut-off system that developed during the last day of the event. It is noteworthy that this third period of high intensity rainfall affected the entire study area, particularly the headwaters of the Gállego River (115 mm at Panticosa; $105 \mathrm{~mm}$ at Lanuza; $104 \mathrm{~mm}$ at Búbal). In general, the records show that rainfall was of lesser importance on 21October.

In summary, the spatial and temporal distribution of precipitation indicates that the storm advanced from northwest to the east and southeast during the first day of the event, linked to the passage of fronts, and that a generalized intense precipitation event occurred during the second day, linked to the cut-off system.

Analysis of historical precipitation series showed that the events of 19 and 20 October ranked generally between the 2nd and 5th highest daily precipitation records, with the exceptions of the 19 October event, which was the highest daily record for Jaca, Javierregay and Isaba, and the 20 October event, which was the highest record for Candanchú. The return periods for the daily events ranged from 12 to 54 years for the 19 October event (with the exceptions of Candanchú, 4 years; and Yesa, 236 years), and from 3 to 24 years for the 20 October event (Table 2). For the two days combined the precipitation was the highest two-day event recorded among all stations with the exception of Panticosa. The return period ranged from 74 to 200 years (with the exceptions of Candanchú, 11 years; and Yesa, 272 years).

\section{Discharge characteristics}

Table 3 shows the main characteristics of the flood in both the Aragón River and its tributaries; the hydrographs are shown in Figure 5. The year 2012 was extremely dry, with precipitation $<60 \%$ of the average in any season of the year, and particularly after May. After a very hot and dry summer the rivers had little flow immediately prior the 
start of the flood at midday on19 October, with discharges of $0.45,2.0$ and $4.1 \mathrm{~m}^{3} \mathrm{~s}^{-1}$ in the Aragón River at Canfranc, Jaca and Martes, respectively; $1.7 \mathrm{~m}^{3} \mathrm{~s}^{-1}$ in the Aragón Subordán River at Javierregay; 0.5 and $0.6 \mathrm{~m}^{3} \mathrm{~s}^{-1}$ in the Veral River at Zuriza and Biniés, respectively; and 0.4 and $0.9 \mathrm{~m}^{3} \mathrm{~s}^{-1}$ in the Esca River at Isaba and Sigüés, respectively.

At Canfranc, which has a drainage area of $70 \mathrm{~km}^{2}$, a peak of $94 \mathrm{~m}^{3} \mathrm{~s}^{-1}$ was recorded for the Aragón River (specific discharge $1349 \mathrm{l} \mathrm{s}^{-1} \mathrm{~km}^{-2}$ ). The peak flow occurred at the beginning of the flood, coinciding with the peak precipitation of $14 \mathrm{~mm}$ in $15 \mathrm{~min}$ at 1910 hours on 19 October. Two minor peaks of 75.7 and $64.5 \mathrm{~m}^{3} \mathrm{~s}^{-1}$ were recorded during 20 October, corresponding to two significantly lower rainfall intensity peaks. The main peak discharge at Canfranc was an underestimate because the fluvial channel overflowed upstream of the gauging station, and it was impossible to estimate the real discharge. At Jaca (drainage area $238 \mathrm{~km}^{2}$ ) the recorded peak discharge was $659 \mathrm{~m}^{3} \mathrm{~s}^{-1}$ (specific discharge $2770 \mathrm{l} \mathrm{s}^{-1} \mathrm{~km}^{-2}$, but this is almost certainly an overestimate, given the peculiar circumstances of the gauging station at Jaca. This is located approximately $60 \mathrm{~m}$ upstream of the bridge over the Aragón River, which was partially dammed by a large mass of trees and branches, blocking the flow. This resulted in the floodwater having to flow through only one of the five spans of the bridge (Fig. 6a), which caused an upstream increase in the water level. The extent to which this affected the gauging station at Jaca is uncertain, making it very difficult to accurately estimate the peak discharge value. However, a comparison between the hydrographs of Canfranc and Jaca provides a basis for discussion.

An initial peak flow (343 $\mathrm{m}^{3} \mathrm{~s}^{-1}$; specific discharge $1439 \mathrm{l} \mathrm{s}^{-1} \mathrm{~km}^{-2}$ ) on the Aragón River at Jaca was recorded at the end of 19 October two hours later than at Canfranc. Afterwards, the hydrograph at Jaca showed some oscillations, including a second short peak flow, and a sudden increase in discharge at the beginning of October 22, which coincided approximately with the third peak flow recorded at the Canfranc gauging station. The latter peak flow was much greater than the discharge expected from the rainfall characteristics, and can be attributed to a riverbank landslide that was triggered near Castiello de Jaca, $10 \mathrm{~km}$ upstream of Jaca. This caused major changes in the streambed (see below) of the Aragón River, and explains the occurrence of the trees that almost completely dammed the river at the bridge at Jaca and increased the water level making it is impossible to estimate the real discharge at Jaca during the third peak flow. According to the steepness of the rising and recessing limb of the second peak 
flow, the maximum discharge could be estimated to have been approximately $500 \mathrm{~m}^{3} \mathrm{~s}^{-}$ 1 (2100 l s-1 km-2). The hydrographs for the other gauging stations throughout the Upper Aragón River basin, and particularly in the Aragón River at Martes, suggest the occurrence of a second peak flow that exceeded the magnitude of the first.

At Martes (30 km downstream of Jaca; drainage area $1083 \mathrm{~km}^{2}$ ), the hydrograph of the Aragón River was complex because of the floodwaters entering from major tributaries between Jaca and Martes, in particular the Estarrún and Aragón Subordán rivers. These river basins were also affected by high precipitation intensity and volume during the rainstorm event. Hydrological data for these tributaries are only available from the Aragón Subordán River at Javierregay (drainage area $348 \mathrm{~km}^{2}$ ). Three peak flows were evident for the Aragón Subordán River, with the first showing a sudden increase coinciding with the period of the greatest rainfall intensity. However, the third of the peak flows was the highest (215 m $\mathrm{m}^{3} \mathrm{~s}^{-1}$; specific discharge $617 \mathrm{l} \mathrm{s}^{-1} \mathrm{~km}^{-2}$ ), but was considerably less than at Canfranc and Jaca, suggesting that the highest intensity rainstorm occurred in the headwaters of the Aragón River.

Interestingly, there is some uncertainty about the time at which the first peak flow occurred. The data for the Aragón River at Martes reflects a sudden increase in discharge at the beginning of the flood, resulting in a first peak at $1445 \mathrm{~h}$ on 19 October. However, at Jaca the first peak in the Aragón River occurred at 1930 h, and in the Aragón Subordán River at Javierregay it was recorded at 1815 h. Therefore, the first pulse in the Aragón River at Martes was not related to the peaks at the other two gauging stations, indicating the occurrence of a marked increase in rainfall intensity close to Martes (i.e. between Jaca and Martes), which probably affected minor ungauged tributaries in the southern part of the basin. The major peak flow of the Aragón River at Martes was not recorded at the gauging station, as there was a break in the hydrograph record between 2230 and 0130 h, during the rising limb of the flood. Based on the steepness of the rising and recessing limbs, the estimated peak flow was approximately $900 \mathrm{~m}^{3} \mathrm{~s}^{-1}$ (specific discharge of $831 \mathrm{l} \mathrm{s}^{-1} \mathrm{~km}^{-2}$ ).

The Veral River enters the Aragón River downstream of Martes, and is gauged at Zuriza (discharge area $47 \mathrm{~km}^{2}$ ) and Biniés $\left(161 \mathrm{~km}^{2}\right)$. The hydrograph for the Veral River at Zuriza (which is close to the headwater) shows an undulating pattern including several peaks and a maximum discharge of $41.5 \mathrm{~m}^{3} \mathrm{~s}^{-1}$ (specific discharge of $882 \mathrm{l} \mathrm{s}^{-1}$ $\mathrm{km}^{-2}$ ). At Biniés, the Veral River showed two main peaks, the latter of which was the most intense (88 $\mathrm{m}^{3} \mathrm{~s}^{-1}$; specific discharge $548 \mathrm{l} \mathrm{s}^{-1} \mathrm{~km}^{-2}$ ). 
The last tributary of the Upper Aragón River is the Esca River, the mouth of which discharges directly into the reservoir. The Esca River is gauged in the headwaters at Isaba (discharge area $191 \mathrm{~km}^{2}$ ) and near the mouth at Sigüés $\left(506 \mathrm{~km}^{2}\right.$ ). The hydrographs for both gauging stations showed two peak flows, with the second higher than the first. The second peak flow occurred at midnight between 20 and 21 October, and was $84 \mathrm{~m}^{3} \mathrm{~s}^{-1}$ at Isaba (440 $\left.\mathrm{l} \mathrm{s}^{-1} \mathrm{~km}^{-2}\right)$ and $248 \mathrm{~m}^{3} \mathrm{~s}^{-1}$ at Sigüés (490 $\mathrm{l} \mathrm{s}^{-1} \mathrm{~km}^{-2}$ ).

The total peak discharge of the Aragón River at Martes, the Veral River at Biniés and the Esca River at Sigüés was approximately $1240 \mathrm{~m}^{3} \mathrm{~s}^{-1}$, to which the discharge of other minor tributaries must be added. Nevertheless, the Yesa reservoir was able to stop the flood, as it was almost empty immediately prior to the flood (Fig. 4). Thus, in the morning of 19 October there was only $72 \mathrm{hm}^{3}$ (16\% of a total capacity of $450 \mathrm{hm}^{3}$ ) stored in the reservoir. The increase in stored volume commenced on the afternoon of 19 October, when the first peak flow of the Aragón and Esca rivers arrived at the reservoir. The volume of the reservoir increased rapidly during 20 and 21 October, reaching a volume of $245 \mathrm{hm}^{3}$ (53\% of the total capacity of the reservoir) at the end of 22 October. Releases of water from the reservoir remained almost stable at a low level: approximately $2.5 \mathrm{~m}^{3} \mathrm{~s}^{-1}$ before and during most of the flood event, except for two minor periods when the discharge was $<20 \mathrm{~m}^{3} \mathrm{~s}^{-1}$. These exemplifies: (i) the very low discharge levels in the Upper Aragón River basin after an extremely dry year, and (ii) the role of the Yesa reservoir in stopping the flood and reducing the risk of floodinduced disaster downstream of the dam, where the Aragón River receives the discharge from one of its main tributaries, the Irati River.

Given the uncertainties associated with some of the estimated discharges (at Canfranc and Jaca, particularly), it is difficult to calculate the return periods to which the discharges correspond. In addition, the validity of return periods for peak discharges in mountain areas is uncertain because of the extreme variability of rainstorm events over short distances (White et al., 1997; García-Ruiz et al., 2001). For this reason, the results must be treated with caution, and considered primarily in terms of detecting differences in the intensity of the rainstorm event within the study area.

Table 3 shows the return periods for the peak discharges in the Upper Aragón River basin, and suggests the presence of two distinct groupings: (i) The relatively moderate return periods associated with the tributaries (e.g., 11.4 years for the Aragón Subordán River at Javierregay; 14 years for the Esca River at Sigüés; 20.4 and 42.5 years for the Veral River at Zuriza and Biniés). (ii) Contrasting with this are the return 
periods associated with the flood in the Upper Aragón River (at Canfranc and Jaca) whis is $>65$ years at Canfranc (and in reality probably much more longer because of the overflow that occurred upstream of the gauging station), and probably 400-500 years at Jaca, if the estimate for the second peak flow is accurate. It was not possible to calculate the return period for the gauging station of Martes, because it has only been in place since 2007. Nevertheless, the total peak flow for the Aragón River including at Martes, the Veral River at Biniés and the Esca River at Sigüés (approximately $1240 \mathrm{~m}^{3} \mathrm{~s}^{-1}$ ) corresponds to a return period of 142 years, which greatly exceeds the return period for the discharge from the tributaries (Table 3).

\section{Floods in other Pyrenean rivers}

West of the Upper Aragón River basin, the flood also affected the Irati River, which is the main tributary of the Aragón River. The evolution of the discharge from the headwaters to the mouth (Fig. 5) confirms the importance of reservoirs in reducing the downstream effects of flooding. Thus, the discharge was $105 \mathrm{~m}^{3} \mathrm{~s}^{-1}$ at Orbaiceta, but only $5.3 \mathrm{~m}^{3} \mathrm{~s}^{-1}$ at Aoiz. Aoiz is immediately downstream of the Itoiz reservoir (417 $\mathrm{hm}^{3}$ ), which was almost empty prior to the flood. Nevertheless, a peak flow of $546 \mathrm{~m}^{3}$ $\mathrm{s}^{-1}$ was recorded in the Irati River at Liédena (drainage area $1546 \mathrm{~km}^{2}$ ), which included

the discharge from its main tributary, the Salazar River (259 $\mathrm{m}^{3} \mathrm{~s}^{-1}$ at Aspurz). The flood continued to increase after the Aragón River received the discharge of the Irati River, with incorporation of the discharge from the Onsella River, a small tributary having a peak flow of $161 \mathrm{~m}^{3} \mathrm{~s}^{-1}$. At Caparroso, close to the mouth into the Ebro River, the peak flow of the Aragón River was $749 \mathrm{~m}^{3} \mathrm{~s}^{-1}$. Each of the gauging stations reflects the occurrence of two peak flows, the second one being the greatest despite the higher intensity of rainfall associated with the first.

It is noteworthy that the only reservoirs in the Irati River basin are located in the headwater (the Irabia reservoir, upstream of the gauging station at Orbaiceta), and in the middle-lower course (the Itoiz reservoir). The remainder of the basin, including the major tributaries of the Irati River (the Salazar and Erro rivers) is not regulated, and nor is the Onsella River, which is a direct tributary of the Aragón River. This explains the differences between the Upper Aragón River and the Irati River when they joined at Liédena. Downstream of the junction the peak flow of the Aragón River was mainly the sum of the peak flows of the Irati and Onsella Rivers. The specific discharge rapidly 
declined downstream (654 l s-1 km-2 at Aspurz, $585 \mathrm{l} \mathrm{s}^{-1} \mathrm{~km}^{-2}$ at Sangüesa, and $137 \mathrm{l} \mathrm{s-1}$ $\mathrm{km}^{-2}$ at Caparroso).

The peak flow of the Ebro River was $789 \mathrm{~m}^{3} \mathrm{~s}^{-1}$ at Castejón de Ebro, and approximately $1000 \mathrm{~m}^{3} \mathrm{~s}^{-1}$ at Zaragoza (Fig. 7). However, close to the headwater, at Miranda, the peak flow was only $36 \mathrm{~m}^{3} \mathrm{~s}^{-1}$, and the hydrograph showed smooth rising and declining limbs.

East of the Aragón River, the Gállego River (Fig. 5) also flooded and three peak flows were recorded at Sallent, close to the spring. This coincided with the occurrence of peak rainfall intensities, the first of which was the largest $\left(62 \mathrm{~m}^{3} \mathrm{~s}^{-1}\right)$. The presence of two reservoirs (the Lanuza and Búbal reservoirs) immediately downstream of Sallent prevented any increase in discharge $\left(1 \mathrm{~m}^{3} \mathrm{~s}^{-1}\right.$ at the foot of the Búbal dam). Nevertheless, the area affected by the rainstorm was sufficiently large to produce a large peak flow downstream of the reservoirs. Thus, the peak flow of the Gállego River recorded at Anzánigo was $609 \mathrm{~m}^{3} \mathrm{~s}^{-1}$. Downstream, a small tributary (the Asabón River) discharges into the Gállego River at La Peña reservoir. During the rainstorm event the Asabón River produced a peak flow of $182 \mathrm{~m}^{3} \mathrm{~s}^{-1}\left(1913 \mathrm{l} \mathrm{s}^{-1} \mathrm{~km}^{-2}\right.$ for a basin of 95 $\mathrm{km}^{2}$ ). This caused a flow increase in the Gállego River that was largely unaffected by the La Peña reservoir, and the flow further increased downstream because of the occurrence of large rainstorms between the Pre-Pyrenees and the Ebro Depression; this was probably enhanced by an orographic effect (228 mm at Asabón; $210 \mathrm{~mm}$ at Loarre).

An extremely large flood was also recorded in the Arba basin, a secondary basin to the south and east of the Aragón basin, the discharge from which directly enters the Ebro River. The Arba basin only drains areas of the Ebro Depression, although the headwater area shows an abrupt increase in gradient at the point where it contacts the Pre-Pyrenees. Intense precipitation was recorded in the uppermost part of the basin and this triggered a large flood in the Riguel River. The peak discharge was impossible to measure because the river overflowed, and the rating curves were not calibrated for extremely large floods. At its lower course, the Arba River recorded a discharge of 272 $\mathrm{m}^{3} \mathrm{~s}^{-1}$ at Tauste, and $316 \mathrm{~m}^{3} \mathrm{~s}^{-1}$ at Gallur. The flooding of the entire alluvial plain at both Tauste and Gallur suggests that these discharge values are underestimates of the real flood. 
In the headwater of the Aragón River (between the spring and the city of Jaca) the intense rainstorms and the flood resulted in damage to the hillslopes and the streambed. Large, deep-seated landslides occurred close to the Spanish-French divide, coinciding with clayey Stephanien outcrops (Fig. 6b). These were typical earthflows, with a scar and a tongue that in some cases directly connected with the main fluvial network or affected the main road. The Aragón River also caused the enlargement of the streambed as a result of erosion of the riverbanks (Fig. 6c), which are composed of relatively unstable glacial or fluvioglacial deposits. This occurred several hundred meters downstream of Canfranc, resulting in enlargement of the alluvial plain (approximately $25 \mathrm{~m}$ ) and development of an armour layer on the surface of the streambed, with coarse blocks and boulders covering the alluvial plain for hundreds of meters.

However, the major change to the stream characteristics occurred in the vicinity of Castiello de Jaca, where the Aragón River eroded part of the fluvioglacial terrace on the left side of the channel. This caused instantaneous input of coarse sediment to the river, which changed its course to the right and eroded part of the main road and destroyed several houses. Figure 8 shows the evolution of the channel between 1998 and 2012. In 1998 the river had two channels (the main one being on the left side) separated by an island covered with typical riparian vegetation dominated by willows (Salix sp.). By 2009 urban areas had been constructed near the right channel at the border of the lowest terrace 1 (terrace 1, approximately 5-6 $\mathrm{m}$ above the fluvial channel). This channel appeared to be nonfunctional, as all the discharge (at least during periods of low water) flowed down the left channel. The October 2012 flood resulted in a change in the fluvial course, which abandoned the main channel and moved back to the right channel, eroding the border of terrace 1 and destroying some of the houses that had been constructed there. A lobe of coarse sediment invaded the alluvial plain because of the sudden erosion of the fluvioglacial terrace in the left side of the channel, isolating the old main channel, which now appears to have been abandoned.

The collapse of part of the fluvioglacial terrace into the river also resulted in a number of trees entering the river, and these were responsible for the partial blockage of the Aragón River at the bridge located immediately downstream of the gauging station at Jaca. This blockage resulted in the sedimentation of coarse debris carried by the river during the peak flow. 
Soil erosion was also substantial on slightly grading cultivated fields of the Inner Depression, where it caused the development of rills and gullies in concavities in fields cropped with winter cereals; this is a common consequence of intense rainfall (GarcíaRuiz, 2010; Outeiro et al., 2010). However, the main sediment sources during the flood (apart from some landslides close to the channel) were probably the badland areas of the Inner Depression, which have good connectivity with the fluvial network (Alatorre and Beguería, 2009, 2011; Nadal-Romero et al., 2009). These badlands yield large quantities of sediment during rainstorm events because they are subject to rapid weathering as a consequence of contrasting temperature and humidity in the regolith (Regüés et al., 2009), and the absence of vegetation. Information on the sediment yield during the 19-21 October rainfall event was obtained from a small experimental catchment (the Araguás catchment) in the badlands, which showed that the badland area of the catchment yielded 15,469 $\mathrm{Mg} \mathrm{km}^{-2}$, with a peak suspended sediment concentration of $497 \mathrm{~g} \mathrm{l}^{-1}$. As the area occupied by badlands in the Inner Depression is approximately $15 \mathrm{~km}^{2}$, the total yield would have been approximately 230,000 $\mathrm{Mg}$ and a large proportion of this would have been carried out to the main river and the Yesa reservoir during the flood, contributing to a reduction of $0.05 \%$ in the capacity of the latter during only one rainfall event. To this figure must be added the sediments derived from elsewhere in the basin, particularly from eroded clays in the headwaters of the Aragón Subordán River, landslides directly connected to the fluvial network, riverbank erosion and erosion on south facing slopes below $1600 \mathrm{~m}$ a.s.l. throughout the entire Aragón River basin, which are not completely protected by forests and dense shrubs (Beguería Portugués, 2005).

\section{DISCUSSION AND CONCLUSIONS}

Intense rainstorms in Mediterranean mountain areas are relatively frequent, particularly in mountain areas close to the coast, and the intensity will probably increase throughout the 21st century (Kysely et al., 2012; Whitfield, 2012), even though the mean precipitation is projected to decline. Historical records indicate that intense rainstorms have triggered large floods in the Pyrenees, and the transport of thousands of tons of sediment (Martí-Bono and Puigdefábregas, 1983; Martí et al., 1997; White et al., 1997). Knowledge of the frequency and magnitude of such floods is extremely important for flood hazard control and forecasting, because of the high velocity and energy of the discharges, which can affect the entire alluvial plain, including cultivated 
fields, urban areas and infrastructure (roads, bridges and dams). The life span of reservoirs also depends on the flood frequency and magnitude, because of the close relationship between extreme events, soil erosion and sediment transport (Antonelli et al., 2008; González Hidalgo et al., 2009; Nadal-Romero et al., 2012).

The 19-21 October 2012 rainfall and flood event in the Upper Aragón River basin showed high spatial variability. Three intense rainfall pulses (the first being the most intense) occurred in most of the study area, corresponding to a return period of 1254 years at most stations. The combined two-day event was more exceptional, with return periods ranging between 74 and 200 years (excluding the two most extreme values). Relatively high variability in the return periods was observed, and questionably high or low values were obtained in at least two stations (Candanchú and Yesa), raising concerns about the adequacy of on-site extreme value analysis for events approaching the highest historical values. One solution, which would require resourcing, is regional extreme value analysis; this considers the information provided by several neighbouring stations to provide a single regional model of extreme event probabilities (Hosking and Wallis, 1997; Gaál and Kysely, 2009). However, several technical problems remain unsolved, including the spatial dependence among stations and the selection of a homogeneous region.

The study of this flood event highlights the difficulties in obtaining accurate information on discharges during extreme events because of the numerous complicating factors involved (e.g. overflowing, and the lack of adequate rating curves for the gauging stations). In this case it was impossible to obtain reliable information on the peak flow from the Canfranc and Jaca gauging stations, although rough estimates were obtained from the shape of the hydrographs. Rainfall data, particularly at Jaca and Javierregay, and the characteristics of the flood as measured at the Aragón River gauging stations suggest that the highest intensity of precipitation and flooding occurred in the Aragón River and not in its tributaries, where the flood corresponded generally to a relatively low return period. This spatial distribution suggests the possible involvement of an orographic effect, whereby humid winds are forced to high altitude in the flysch sector and the Inner Sierras, particularly around the Collarada Massif. Other reliefs in the southern versant of the Aragón basin (Oroel and San Juan de la Peña massifs) may have contributed to the occurrence of very intense rainfall, as suggested by the rise of the Aragón River between the Jaca and Martes gauging stations. Topographic forcing also occurred where the Ebro Depression and the Pre-Pyrenees 
meet, resulting in local intense rainstorms and extreme floods. This spatial variability demonstrates the difficulty of forecasting the location of the most intense rainstorm nucleus, and indicates the importance of appropriate management of infrastructure, livestock farms and human settlements. It also emphasizes the largely irregular distribution of intense rainstorms in mountain areas because of orographic effects, and the changing relationship between aspect and the dominant wind direction during an event. It is noteworthy that the occurrence of localized horizontal and vertical turbulence favours the development of small thermodynamically unstable cells, which can result in extremely intense rainstorms that are rarely recorded at the weather stations.

Two peak flows were recorded at most of the gauging stations. In general, the main peak flow occurred during the second or third peak rainfall intensities. This is probably a consequence of the drought that affected the Pyrenees and the Ebro Depression in 2012, which enhanced water infiltration at the beginning of the event and delayed the peak flow for several hours. The second peak flow was particularly intense at Jaca and Martes.

The role of reservoirs in controlling floods is a matter of major interest. LópezMoreno et al. (2002a) demonstrated that reservoirs in Mediterranean mountains show extreme variability in their capacity to store incoming floodwaters, depending on the water level in the reservoir, and the season in which the event occurs. In the case of the Aragón basin, the Yesa reservoir was able to retain the floodwaters of the Aragón River, such that no flood was recorded at the foot of the dam, even though the reservoir storage changed from 16 to $53 \%$ as a consequence of the event. In the Irati River, no flood discharge was detected at the foot of the Itoiz reservoir, although the discharge rapidly increased with inputs from the Erro, Salazar and Onsella rivers, which caused a large flood in the lower course of the Aragón River and a moderate one in the Ebro River. Thus, the flood in the lower course of the Aragón River was caused by water from the unregulated tributaries of the Irati River. Without the Yesa and Itoiz reservoirs there would have been a major flood in the Aragón and Ebro rivers. This highlights the important role of reservoirs, particularly when they are at low leveles of water storage (López-Moreno et al., 2004). Thus, the Yesa reservoir controls most of the floods that occur in autumn, when the storage level is at its lowest (López-Moreno et al. 2002 a, 2002 b).

In the case of the Gállego River, the reservoirs in the headwaters (Lanuza and Búbal) significantly reduced the consequences of the flood, whereas the La Peña 
reservoir, in the middle course of the river, was not able to control the flood, particularly when a small tributary (the Asabón River) underwent an extreme flood. Consequently, very high discharges of floodwater were recorded in the lower course of the Gállego River.

The 19-21 October flood can also be considered in relation to the role of plant cover in controlling extreme rainfall events. Farmland abandonment in the central Pyrenees in the last 50 years resulted in colonization of the abandoned cultivated fields with dense shrubs and forests, changing the relationship between annual precipitation and discharge, and reducing the stream flow in Pyrenean rivers (Beguería et al., 2003; García-Ruiz and Lana-Renault, 2011). Over this period the maximum annual peak discharge has progressively declined, whereas the maximum 24-hour precipitation values have remained stable (López-Moreno et al., 2006), indicating that plant cover can influence the intensity of the most frequent floods. Studies in experimental catchments under various land covers in the Pyrenees have revealed that the response of different catchments to intense rainstorms varies according to plant cover structure and density, and the history of land use (García-Ruiz et al., 2008; Lana-Renault et al., 2011), confirming that land use change can be as effective from a hydrological point of view as changes in climate (Whitfield, 2012). Nevertheless, the influence of plant cover is less evident in the case of extreme events because of its limited role in intercepting rainfall, as has been demonstrated for long-lasting and/or intense rainstorms on densely covered areas (White et al., 1997; Llorens and Domingo, 2007). Thus, the San Salvador catchment is covered by a dense mixed forest of beech, oak and pine, but flash floods can occur during intense spring rainstorms following a rainy period that raises the water table (Serrano-Muela et al., 2008). The complex interrelationships among exceptional rainstorm events, orography, land cover and the location of infrastructure and settlements indicate the need for integrated studies. This is particularly the case for mountain areas, where the steep slopes and longitudinal gradients of the rivers shorten the concentration time of flood, increase the available energy for channel and river bank erosion, and increase the difficulties in preventing flood hazards.

This paper confirms the complexity of floods in large basins, where the spatial distribution of the rainfall, the characteristics of the plant cover, and the heterogeneous topography explain that the main river and its tributaries were activated at different moments. In the case of the Upper Aragón River basin, this complexity reduced the influence of rainfall intensity on flood generation, as suggested by Bracken et al. (2008). 
The combined two-day event of 19-20 October 2012 was the most extreme two-day event among all observation stations but one. In spite of that, the flood cannot be considered as extreme, mainly due to the long dry period during the previous months, and the low water levels of the two main reservoirs of the Aragón River basin, the Yesa and Itoiz reservoirs, which retained most of the flood.

\section{ACKNOWLEDGEMENTS}

Support for this research was provided by the projects INDICA (CGL2011-27753-C0201 and -02), DISPROSPEC (CGL2011-24185) and HIDROCAES (CGL2011-27574C02-01), funded by the Spanish Ministry of Economy and Innovation; ACQWA (FP7ENV-2007-1-212250), financed by the European Commission; and an agreement between the CSIC and the Spanish Ministry of Environment (RESEL). The research group on Geomorphology and Global Change was financed by the Aragón Government and the European Social Fund (ESF-FSE). E. Nadal-Romero and N. Lana-Renault benefited from a research contract (Spanish Ministry of Economy and Innovation, Programme Juan de la Cierva). The authors acknowledge the free availability of the hydrological information from the Ebro River Authority, and the help provided by the team of the Centro de Proceso de Cuenca del Sistema Automático de Información Hidrológica de la Confederación Hidrográfica del Ebro. The cartographic help from Paz Errea and Sergio Valdivielso was also acknowledged.

\section{REFERENCES}

Acín V, Ballarín D, Brufao P, Domenech S, Espejo F, González-Hidalgo JC, Granado, D., Ibisate, A., Marcén, C., Mora, D., Nadal-Romero, E., Ollero, A., Sánchez-Fabre, M., Saz, M.A., Serrano, R. 2012. Sobre las precipitaciones de octubre de 2012 en el Pirineo aragonés, su respuesta hidrológica y la gestión de riesgos. Geographicalia 61: 101-128.

Alatorre LC, Beguería,S. 2009. Identificación de zonas de erosión activa y áreas de riesgo mediante teledetección: un ejemplo en un paisaje de cárcavas sobre margas en el Pirineo Central Español. Cuadernos de Investigación Geográfica 35 (2): 171-194.

Alatorre LC, Beguería S, Vicente-Serrano S. 2011. Evolution of vegetation activity on vegetated, eroded, and erosion risk areas in the central Spanish Pyrenees, using multitemporal Landsat imagery. Earth Surface Processes and Landforms 36: 309319. 
Antonelli C, Eyrelee F, Rolland B, Provansal M, Sabatier F. 2008. Suspended sediment and 137Cs fluxes during the exceptional December 2003 flood in the Rhone River, southeast France. Geomorphology 95: 350-360.

Beguería S. 2005. Erosión y Fuentes de sedimento en la Cuenca del embalse de Yesa (Pirineo Occidental): Ensayo de una metodología basada en teledetección y análisis SIG. Instituto Pirenaico de Ecología, Zaragoza, 158 pp.

Beguería S, López-Moreno JI, Lorente A, Seeger M, García-Ruiz JM. 2003. Assessing the effect of climate oscillations and land-use changes on streamflow in the Central Spanish Pyrenees. Ambio 32: 283-286.

Benito G, Grodek T, Enzel Y. 1998. The geomorphic and hydrologic impacts of catastrophic failure of flood-control-dams during the 1996 Biescas flood (Central Pyrenees, Spain). Zeitschrift für Geomorphologie 42: 417-437.

Bracken LJ, Cox NJ, Shannon J 2008. The relationship between rainfall inputs and flood generation in south-east Spain. Hydrological Processes 22: 683-696.

Calvet M, Lemartinel B. 2002. Précipitations exceptionnelles et crues-éclair dans l'aire pyreneo-méditerranéenne. Géomorphologie: Relief, Processus, Environnement 1: 35-50.

Camarasa Belmonte AM, Segura Beltrán F. 2001. Flood events in Mediterranean ephemeral streams (ramblas) in Valencia region, Spain. Catena 45: 229-249.

Cole S. 2001. An introduction to statistical modelling of extreme values. Springer Verlag, London.

Gaál L, Kysely J. 2009. Comparison of region-of-influence methods for estimating high quantiles of precipitation in a dense dataset in the Czech Republic. Hydrology and Earth System Sciences 13: 2203-2219.

García-Ruiz JM. 2010. The effects of land uses on soil erosion in Spain: A review. Catena 81: 1-11.

García-Ruiz JM, Lana-Renault N. 2011. Hydrological and erosive consequences of farmland abandonment in Europe, with special reference to the Mediterranean region - A review. Agriculture, Ecosystems and Environment 140: 317-338.

García-Ruiz JM, Arnáez J, White SM. Lorente A, Beguería S. 2000. Uncertainty assessment in the prediction of extreme rainfall events: an example from the central Spanish Pyrenees. Hydrological Processes 14: 887-898. 
García-Ruiz JM, Beguería S, López-Moreno JI, Lorente A, Seeger M. 2001. Los recursos hídricos superficiales del Pirineo aragonés y su evolución reciente. Geoforma Ediciones, Logroño, 102 pp.

García-Ruiz, JM, Regüés D, Alvera B, Lana-Renault N, Serrano-Muela P, NadalRomero E, Navas A, Latron J, Martí-Bono C, Arnáez J. 2008. Flood generation and sediment transport in experimental catchments along a plant cover gradient in the Central Pyrenees. Journal of Hydrology 356: 245-260.

Gaume E, Bain V, Bernardara P, Newinger O, Barbuc M, Bateman A, Blaskovikova L, Bloschl G, Borga M, Dumitrescu A, Daliakopoulos I. García J, Irimescu A, Kohnova S, Koutroulis A, Marchi L, Matreata S, Medina V. Preciso E, Sempere-Torres D, Stancalie G, Szolgay J, Tsanis I, Velasco D, Viglione A. 2009. A compilation of data on European flash floods. Journal of Hydrology 367: 70-78.

González-Hidalgo JC, de Luis M, Batalla RJ 2009. Effects of the largest daily events on total soil erosion by rainwater. An analysis of the USLE database. Earth Surface Processes and Landforms 34: 2070-2077.

González-Hidalgo JC, de Luis M, Raventós J, Sánchez JR. 2003. Daily rainfall trend in the Valencia region of Spain. Theoretical and Applied Climatology 75: 117-130.

Grodek T, Jacoby Y, Morin E, Katz O. 2012. Effectiveness of exceptional rainstorms on a small Mediterranean basin. Geomorphology 159-160: 156-168.

Hosking JRM, Wallis JR. 1997. Regional frequency analysis: an approach based on Lmoments. Cambridge University Press, Cambridge, 244 pp.

Jacobson RB, Miller AJ, Smith JA. 1989. The role of catastrophic geomorphic events in central Appalachian landscape evolution. Geomorphology 2: 257-284.

Kysely J, Beguería S, Beranová R, Gaál L, López-Moreno JI. 2012. Different patterns of climate change scenarios for short-term and multi-day precipitation extremes in the Mediterranean. Global and Planetary Change 98-99: 63-72.

Lana-Renault N, Latron D, Karssenberg D, Serrano P, Regüés D, Bierkens MFP. 2011. Differences in stream flow in relation to changes in land cover: a comparative study in two sub-Mediterranean mountain catchments. Journal of Hydrology 411: 366-378.

Lasanta T, Vicente-Serrano SM, Cuadrat-Prats JM. 2005. Mountain Mediterranean landscape evolution caused by the abandonment of traditional primary activities: A study of the Spanish Central Pyrenees. Applied Geography 25: 47-65.

Llorens P, Domingo F. 2007. Rainfall partitioning by vegetation under Mediterranean conditions. A review of studies in Europe. Journal of Hydrology 335: 37-54. 
López-Bermúdez F, Romero-Díaz MA 1993. Génesis y consecuencias erosivas de las lluvias de alta intensidad en la region mediterránea. Cuadernos de Investigación Geográfica 18-19: 7-28.

López-Moreno JI. 2006. Cambios ambientales y gestión de los embalses en el Pirineo Central español. Publicaciones del Consejo de Protección de la Naturaleza de Aragón, Zaragoza, 208 pp.

López-Moreno JI, Beguería S, García-Ruiz JM. 2002 a. Influence of the Yesa reservoir on floods of the Aragón River, central Spanish Pyrenees. Hydrology and Earth System Sciences 64: 753-762.

López-Moreno JI, Beguería S, García-Ruiz JM. 2002 b. Floods downstream the Yesa reservoir, Spanish Pyrenees. Cuadernos de Investigación Geográfica 28: 101-108.

López-Moreno JI, Beguería S, García-Ruiz JM. 2004. The management of a large Mediterranean reservoir: Storage regimens of the Yesa reservoir, Upper Aragón River basin, Central Spanish Pyrenees. Environmental Management 34: 508-515.

López-Moreno JI, Beguería S, García-Ruiz JM. 2006. Trends in high flows in the Central Spanish Pyrenees: response to climatic factors or to land-use change? Hydrological Sciences Journal 51: 1039-1050.

Martí C, Valero B, García-Ruiz JM. 1997. Large, historical debris flows in the Central Spanish Pyrenees. Physics and Chemistry of the Earth 22: 351-354.

Martí-Bono C. Puigdefábregas J. 1983. Consecuencias geomorfológicas de las lluvias de noviembre de 1982 en las cabeceras de algunos valles pirenaicos. Estudios Geográficos 170-171: 275-289.

Nadal-Romero E, Lasanta T, González-Hidalgo JC, de Luis, M, García-Ruiz JM. 2012. The effect of intense rainstorm events on the suspended sediment response under various land uses: The Aísa Valley experimental station. Cuadernos de Investigación Geográfica 38 (1): 27-47.

Nadal-Romero, E., Regüés, D., Latron, J., Lana-Renault, N., Serrano-Muela, M.P., Martí-Bono, C. 2009. Funcionamiento hidrológico de una pequeña cuenca con morfologías acarcavadas en el Pirineo Central. Cuadernos de Investigación Geográfica 35 (1): 119-139.

Nieto R, Gimeno L, de la Torre L, Ribera P, Gallego D, García-Herrera R, García JA, Lorente J. 2005. Climatological features of cutoff low systems in the Northern Hemisphere. Journal of Climate 18: 3085-3103. 
Ortega JA, Garzón Heydt G. 2009. Geomorphological and sedimentological analysis of flash-flood deposits. The case of the 1997 Rivillas flood (Spain). Geomorphology 112: 1-14.

Outeiro L, Úbeda X, Farguell J. 2010. The impact of agriculture on solute and suspended sediment load on a Mediterranean watershed after intense rainstorms. Earth Surface Processes and Landforms 35: 549-560.

Poesen JWA, Hooke JM. 1997. Erosion, flooding and channel management in Mediterranean environments of southern Europe. Progress in Physical Geography 21 (2): 157-199.

Regüés D, Nadal-Romero E, Latron J, Martí-Bono C. 2009. Producción y transporte de sediment en cárcavas desarrolladas en la Depresión Interior Altoaragonesa (Cuenca de Araguás, Pirineo Central). Cuadernos de Investigación Geográfica 35 (2): 263287.

Romero Díaz MA, Cabezas F, López Bermúdez F. 1992. Erosion and fluvial sedimentation in the River Segura Basin (Spain). Catena 19: 379-392.

Serrano-Muela MP, Lana-Renault N, Nadal-Romero E, Regüés D, Latron J, Martí-Bono C, García-Ruiz JM. 2008. Forests and their hydrological effects in Mediterranean mountains. Mountain Research and Development 28: 279-285.

Thornes JB. 1976. Semi-arid erosional systems. Occasional Paper 7, School of Economics, London.

Wainwright J, Thornes JB. 2004. Environmental issues in the Mediterranean. Processes and perspectives from the past and present. Routledge, London, $479 \mathrm{pp}$.

White S, García-Ruiz JM, Martí C, Valero B, Errea MP, Gómez-Villar A. 1997. The 1996 Biescas campsite disaster in the Central Spanish Pyrenees, and its temporal and spatial context. Hydrological Processes 11: 1797-1812.

Whitfield PH. 2012. Floods in future climates: a review. Journal of Flood Risk Management 5: 336-365.

Wolman MG, Gerson R. 1978. Relative scales of time and effectiveness of climate in watershed geomorphology. Earth Surface Processes and Landforms 3: 189-208.

\section{FIGURE CAPTIONS}

Figure 1. The study area and the location of the weather stations. Black dots: weather stations (see Table 1).

Figure 2. Regime of the Aragón River at Jaca. 
Figure 3. Rainfall distribution during the 19-20 October 2012 rainstorm event. Corrected from Acín et al. (2012), with permission from the authors.

Figure 4. The evolution of the synoptic conditions during the rainfall event of 19-20 October 2012. Source: National Meteorological Agency (AEMET).

Figure 5. Flood hydrographs for the Aragón, Irati and Gállego River basins. Horizontal axis: October days. Vertical axis: Discharge $\left(\mathrm{m}^{3} \mathrm{~s}^{-1}\right)$.

Figure 6. Some effects of the 19-21 October flood. 6a: The bridge over the Aragón River at Jaca, dammed by a large mass of trees carried by the floodwaters. 6b: Landslide affecting Stephanian clays, close to the Spanish-French border (Upper Aragón basin). 6c: Enlargement of the streambanks affected by lateral erosion during the flood (Aragón River downstream of Canfranc).

Figure 7. Flood hydrographs for the middle course of the Ebro River. Horizontal axis: October days. Vertical axis: Discharge $\left(\mathrm{m}^{3} \mathrm{~s}^{-1}\right)$.

Figure 8. Change in the course of the Aragón River in the vicinity of Castiello de Jaca. The occurrence of a landslide in the fluvial terrace forced the river course to the right, destroying part of an urban area constructed during the last decade. 
Table 1. The spatial and temporal distribution of the rainfall. The maximum values are represented in bold type.

Numbers in column 1 indicate the western-eastern spatial distribution of the rain gauges. Loarre, Sotonera and Gállego-Zgz are located in the Ebro Depression. Numbers in column 2 represent the weather stations numbered in Figure 1.

\begin{tabular}{|c|c|c|c|c|c|c|}
\hline & & $\begin{array}{l}\text { Weather } \\
\text { stations }\end{array}$ & Total & $\begin{array}{c}19 \text { October } \\
\mathbf{5 . 1 5} \mathbf{h}-\mathbf{1 4 . 3 0} \\
\mathbf{h} \\
\end{array}$ & $\begin{array}{c}19-20 \\
\text { October } \\
\mathbf{1 4 . 3 0} \text { h } \mathbf{2 . 0 0} \\
\mathbf{h} \\
\end{array}$ & $\begin{array}{c}20 \text { October } \\
\mathbf{2 . 0 0} \mathbf{h}-\mathbf{2 3 . 4 5} \\
\mathbf{h} \\
\end{array}$ \\
\hline \multirow{5}{*}{1} & 1 & Burguete & 148.8 & 46.6 & 9.8 & 77.8 \\
\hline & 2 & Irabia & 200.4 & 76.4 & 17.2 & 92.2 \\
\hline & 3 & Anduñana & 253.0 & 147.2 & 18.0 & 71.4 \\
\hline & 4 & Itoiz & 143.0 & 38.6 & 4.7 & 85.2 \\
\hline & 5 & Irati & 181.2 & 74.4 & 7.6 & 84.0 \\
\hline \multirow{4}{*}{2} & 6 & Belagua & 253.0 & 91.6 & 41.8 & 99.6 \\
\hline & 7 & Isaba & 248.8 & 94.0 & 30.2 & 90.6 \\
\hline & 8 & Sigüés & 153.6 & 40.6 & 19.0 & 80.0 \\
\hline & 9 & Yesa & 214.6 & 122.2 & 9.4 & 74.2 \\
\hline \multirow{5}{*}{3} & 10 & Zuriza & 190.6 & 67.8 & 30.6 & 61.6 \\
\hline & 11 & Ansó & 131.4 & 39.8 & 46.6 & 29.4 \\
\hline & 12 & Sueña & 174.8 & 81.0 & 21.0 & 65.2 \\
\hline & 13 & Biniés & 198.0 & 95.0 & 25.0 & 68.2 \\
\hline & 14 & Martes & 167.8 & 64.2 & 21.0 & 73.4 \\
\hline \multirow{2}{*}{4} & 15 & Hecho & 208.8 & 94.8 & 31.4 & 71.8 \\
\hline & 16 & Javierregay & 253.3 & 92.8 & 37.9 & 109.0 \\
\hline \multirow{3}{*}{5} & 17 & Candanchú & 240.0 & 26.8 & 112.4 & 90.4 \\
\hline & 18 & Canfranc & 234.6 & 9.8 & 138.6 & 77.0 \\
\hline & 19 & Albarún & 215.6 & 6.6 & 127.4 & 70.6 \\
\hline \multirow{8}{*}{6} & 20 & Formigal & 191.0 & 38.4 & 47.6 & 83.6 \\
\hline & 21 & Lanuza & 208.7 & 34.8 & 53.1 & 104.9 \\
\hline & 22 & Panticosa & 222.2 & 40.0 & 54.8 & 115.2 \\
\hline & 23 & Búbal & 199.2 & 24.8 & 54.7 & 103.5 \\
\hline & 24 & Betés & 176.4 & 28.6 & 43.8 & 93.8 \\
\hline & 25 & Yésero & 172.2 & 24.0 & 34.6 & 100.4 \\
\hline & 26 & Aineto & 95.4 & 14.2 & 7.8 & 64.8 \\
\hline & 27 & Asabón & 228.2 & 96.0 & 19.2 & 101.4 \\
\hline
\end{tabular}




\begin{tabular}{ccccccc} 
& 28 & Loarre & 210.6 & 29.0 & $\mathbf{7 0 . 4}$ & $\mathbf{1 0 0 . 0}$ \\
7 & 29 & Sotonera & 106.0 & 18.5 & 21.8 & $\mathbf{5 7 . 2}$ \\
& & Gállego-Zgz & 66.0 & 0.4 & 6.8 & 48.6 \\
\hline
\end{tabular}

Table 2. Estimated return periods at various stations. Name: station name; Alt: station altitude; Length: record length (years); P: precipitation; T: return period (years); n.a.: not available.

\begin{tabular}{lcccccccc}
\hline Name & $\begin{array}{c}\text { Alt } \\
(\mathrm{m})\end{array}$ & $\begin{array}{c}\text { Length } \\
(\mathrm{y})\end{array}$ & $\begin{array}{c}\text { P19th } \\
(\mathrm{mm})\end{array}$ & $\begin{array}{c}\text { T19th } \\
(\mathrm{y})\end{array}$ & $\begin{array}{c}\text { P20th } \\
(\mathrm{mm})\end{array}$ & $\begin{array}{c}\text { T20th } \\
(\mathrm{y})\end{array}$ & $\begin{array}{c}\text { P19-20th } \\
(\mathrm{mm})\end{array}$ & $\begin{array}{c}\text { T19-20th } \\
(\mathrm{y})\end{array}$ \\
\hline Panticosa & 1660 & 43 & 107 & 12 & 115 & 20 & 222 & 74 \\
Candanchú & 1613 & 20 & 112 & 4 & 128 & 7 & 240 & 11 \\
Canfranc & 1075 & 61 & 139 & 27 & 96 & 3 & 235 & 76 \\
Loarre & 790 & 49 & 111 & 13 & 100 & 9 & 211 & 200 \\
Jaca & 800 & 30 & 127 & 33 & n.a. & n.a. & n.a. & n.a. \\
Javierregay & 690 & 45 & 130 & 54 & 109 & 24 & 235 & 112 \\
Yesa & 515 & 61 & 132 & 236 & 83 & 15 & 215 & 272
\end{tabular}

Table 3. Main characteristics of the 19-21 October flood and return periods in the Aragón River basin.

\begin{tabular}{|c|c|c|c|c|c|c|c|}
\hline River & Gauging station & $\begin{array}{l}\text { Basin } \\
\text { area } \\
\left(\mathrm{Km}^{2}\right)\end{array}$ & $\begin{array}{c}\text { Average } \\
\text { discharge } \\
\left(\mathrm{m}^{3} \mathrm{~s}^{-1}\right)\end{array}$ & 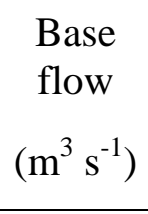 & $\begin{array}{c}\text { Peak } \\
\text { discharge } \\
\left(\mathrm{m}^{3} \mathrm{~s}^{-1}\right)\end{array}$ & 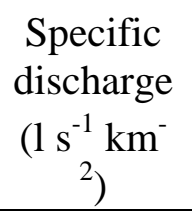 & $\begin{array}{l}\text { Return } \\
\text { period }\end{array}$ \\
\hline Aragón & Canfranc & 70 & 1.8 & 0.5 & 94 & 1349 & 65 \\
\hline Aragón & Jaca & 238 & 6.4 & 2.0 & $500 *$ & $2100^{*}$ & 488 \\
\hline $\begin{array}{l}\text { Aragón- } \\
\text { Subordán }\end{array}$ & Javierregay & 348 & 11.7 & 1.7 & 215 & 617 & 11.4 \\
\hline Veral & Zuriza & 47 & 1.8 & 0.5 & 41.5 & 882 & 20.4 \\
\hline Veral & Biniés & 161 & 4.1 & 0.6 & 88.2 & 548 & 42.5 \\
\hline Aragón & Martes & 1083 & 30.1 & 4.1 & $900 *$ & $831 *$ & - \\
\hline Esca & Isaba & 191 & n.a. & 0.4 & 84 & 440 & - \\
\hline Esca & Sigüés & 506 & 10.9 & 0.9 & 248 & 490 & 14 \\
\hline Aragón & $\begin{array}{l}\text { Head of the Yesa } \\
\text { dam }\end{array}$ & - & - & - & 1250 & - & 142 \\
\hline
\end{tabular}




\begin{tabular}{|c|c|c|c|c|c|}
\hline Aragón & $\begin{array}{l}\text { Foot of the Yesa } \\
\text { dam }\end{array}$ & 2191 & 44.9 & 2.5 & 19 \\
\hline
\end{tabular}

